ZOOLOGIA 30 (3): 346-352, June, 2013

http://dx.doi.org/10.1590/S1984-46702013000300015

\title{
Morphology of immatures of Euschistus (Mitripus) grandis (Insecta: Hemiptera: Pentatomidae)
}

\section{Larissa Donida Biasotto1, Filipe Michels Bianchi1 \& Luiz Alexandre Campos ${ }^{1,2}$}

\author{
1 Departamento de Zoologia, Instituto de Biociências, Universidade Federal do Rio Grande do Sul. Avenida Bento Gonçalves \\ 9500, Prédio 43435, 91501-970 Porto Alegre, RS, Brazil. \\ 2 Corresponding author. E-mail: luiz.campos@ufrgs.br
}

\begin{abstract}
Immatures are important sources of information about characters, thus potentially improving classification and phylogenies. Euschistus (Mitripus) grandis Rolston, 1978 occurs in southern and southeastern Brazil. There are no references in the literature about this species other than the original description and distribution records. Our aim is to describe the egg and five nymphal instars of $E$. (M.) grandis, addressing the ontogeny of the external scent efferent system. Specimens of E. (M.) grandis were collected on Solanum pseudocapsicum Linnaeus (Solanaceae) in São Francisco de Paula, Rio Grande do Sul, Brazil, and reared in the laboratory. The egg of E. (M.) grandis is white and barrel-shaped, chorion translucent bearing spines connected by thin sheets forming polygons. Aero-mycropilar processes translucent and slightly clubbed. The nymphs bear anterior dorsal abdominal scent glands (DAG) with slit-like ostiole continued by a short groove; from the second instar onward median and posterior DAGs with rounded ostiole bearing closing cuticular valve. Spout peritreme flat and curved anteriorly, evaporatorium network-shaped surrounding ostiole plus peritrema; alveoli surface with trabeculae. Nymphs of E. (M.) grandis can be distinguished from other species of Euschistus by the color pattern and morphological features. The most striking morphological characteristic of $4^{\text {th }}$ and $5^{\text {th }}$ instar nymphs of E. (M.) grandis is the broad, deflected projection of humeral angles.
\end{abstract}

KEY WORDS. Brown stink bug; Carpocorini; chorion sculpturing; dorsal abdominal glands; nymph.

Studies on autoecology, behavior and morphology of immatures of insects are relevant for several fields in entomology (BRAllovsky et al. 1992). For taxonomic purposes, the immatures are important sources of information about characters, thus potentially improving classification and phylogenies (MATEsco et al. 2009). Characters of immatures, both eggs and nymphs, can be useful to identifying families, genera and species (SCHWERTNer et al. 2002). In ecological studies the use of immatures to evaluate the local diversity allows a better description and understanding of the ecological dynamics (MENDONÇA et al. 2009), although nymphs are commonly excluded from such studies because of the difficulty or even impossibility of identification. Also, early identification of crop pests in agroecosystems enables a faster adoption of control strategies (Brailovsky et al. 1992).

Most pentatomids are phytophagous and some species are crop pests (Grazia et al. 1999). This economic aspect stimulated studies on immature stages of the Pentatomidae and the family is the most thoroughly studied for biological aspects among the Heteroptera (BRAILOvsKy et al. 1992, YonKE 1991). Nevertheless, only 146 out of almost 5,000 species of pentatomids have the eggs or nymphs described (Pollo et al. 2012). The number of morphological descriptions has increased in the last two decades (see MAtesco et al. 2009) and most recent studies focus on the evaluation of neglected structures, potentially bearing phylogenetic information (e.g., dorsal abdominal scent glands, DAGs). Recent studies also employ scanning electron microscopy (SEM) techniques that allow more detailed descriptions, with relevant morphological features found (e.g., Bianchi et al. 2011, Pollo et al. 2012, Gilio-Dias et al. 2013). The phylogenetic importance of the egg stage was demonstrated in cladistic analyses (HASAN \& Kitching 1993, Wheeler et al. 1993, Henry 1997, Grazia et al. 2008), while the relevance of DAGs in phylogenies was not explored.

Euschistus Dallas, 1851 is among the largest genera of Pentatomidae, comprising about 76 species distributed in the Neotropical and Nearctic regions. Euschistus (Mitripus) Rolston, 1978 is composed by ten species, with available information about immature stages for Euschistus (M.) convergens (HerrichSchäffer, 1842) and Euschistus (M.) hansi Grazia, 1987 (Martins \& Campos 2006, Matesco et al. 2009).

Euschistus (M.) grandis occurs in southern and southeastern Brazil, recorded from sites between 800 and 1,700 m of altitude (Rolston 1978). There are no references in the literature about the species other than the original description and distribution records. Our aim is to describe the egg and five nymphal instars of E. (M.) grandis, addressing the ontogeny of the external scent efferent system using light and scanning electron microscopy. 


\section{MATERIAL AND METHODS}

Adults of E.(M.) grandis were collected on Solanum pseudocapsicum Linnaeus (Solanaceae) in São Francisco de Paula, Rio Grande do Sul, Brazil (29²5’44.99"S, 50²3'36.49"W), from April to December 2011. Couples of specimens were maintained in plastic pots until oviposition. Eggs were transferred to Petri dishes with a moistened cotton pad. From eclosion to fifth instar the specimens were reared in pots, and fed on branches of S. pseudocapsicum with fruit and a pod of Phaseolus vulgaris Linnaeus (Fabaceae). Petri dishes were inspected daily; water and food were replaced whenever necessary.

Measurements, given in millimeters, were obtained according to Campos et al. (2010), from ten eggs and ten individuals of each instar, maintained in 70\% ethanol (Table I). Description of color pattern was carried out in vivo. Terminology for eggs and nymphs follows respectively MATEsco et al. (2009) and Matesco et al. (2006, 2007). Terminology for the cuticular structures of dorsal abdominal scent glands (DAG) of nymphs follows KMENT \& Vilímová (2010) as proposed by Bianchi et al. (2011), and Vilímová \& Kutalová (2012). For scanning electron microscopy (SEM) analysis of the chorion and nymphs we adopted the protocol described by BIANCHI et al. (2011).

Voucher specimens were deposited in the Coleção Entomológica do Departmento de Zoologia, Universidade Federal do Rio Grande do Sul (UFRS), Porto Alegre.

\section{RESULTS}

Egg (Figs 1-3). White, barrel-shaped, operculum convex, length $1.47 \pm 0.08$ (1.40-1.68), width $1.26 \pm 0.03$ (1.22-1.32) (Fig. 1). Chorion translucent, red eyes and brownish ruptor ovis visible in developing embryo. Chorion spinose under SEM, spines connected by thin sheets forming irregular polygons. Aero-mycropilar processes (AMP) in number of $39.3 \pm 4.7$ (3147), translucent, slightly clubbed (Fig. 2); surface spongy under SEM; bearing apical opening (Fig. 3).

Table I. Measurements in millimeters (mean \pm deviation, minimum - maximum, $\mathrm{n}=10$ ) of morphometric parameters of nymphs of Euschistus (Mitripus) grandis reared under controlled conditions. (AL, AW) Abdominal length and width, (HL, HW) head length and width, (ID) interocular distance, (I, II, III, IV) $1^{\text {st }}$ to $4^{\text {th }}$ antennal segments, (RL) rostrum length, (THL, THW) thorax length and width, (TL) total length.

\begin{tabular}{|c|c|c|c|c|c|}
\hline & $1^{\text {st }}$ instar & $2^{\text {nd }}$ instar & $3^{\text {rd }}$ instar & $4^{\text {th }}$ instar & $5^{\text {th }}$ instar \\
\hline \multirow[t]{2}{*}{$\mathrm{TL}$} & $1.83 \pm 0.11$ & $2.96 \pm 0.16$ & $4.20 \pm 0.39$ & $6.30 \pm 0.57$ & $9.20 \pm 0.54$ \\
\hline & $(1.7-2.04)$ & $(2.79-3.24)$ & $(3.64-5.08)$ & $(5.62-7.50)$ & $(8.20-10.00)$ \\
\hline \multirow[t]{2}{*}{$\mathrm{HL}$} & $0.62 \pm 0.07$ & $0.77 \pm 0.81$ & $1.05 \pm 0.08$ & $1.37 \pm 0.12$ & $1.88 \pm 0.21$ \\
\hline & $(0.48-0.74)$ & $(0.65-0.92)$ & $(0.92-1.16)$ & $(1.25-1.56)$ & $(1.60-2.37)$ \\
\hline \multirow[t]{2}{*}{ HW } & $0.79 \pm 0.02$ & $0.96 \pm 0.02$ & $1.21 \pm 0.06$ & $1.51 \pm 0.18$ & $2.08 \pm 0.06$ \\
\hline & $(0.76-0.82)$ & $(0.92-1.00)$ & $(1.08-1.28)$ & $(1.25-1.75)$ & $(2.00-2.20)$ \\
\hline \multirow[t]{2}{*}{ ID } & $0.58 \pm 0.01$ & $0.60 \pm 0.06$ & $0.75 \pm 0.03$ & $0.95 \pm 0.05$ & $1.30 \pm 0.12$ \\
\hline & $(0.56-0.60)$ & $(0.44-0.68)$ & $(0.68-0.80)$ & $(0.87-1.04)$ & $(1.10-1.50)$ \\
\hline \multirow[t]{2}{*}{ RL } & $0.97 \pm 0.05$ & $1.70 \pm 0.27$ & $2.49 \pm 0.13$ & $3.29 \pm 0.31$ & $4.50 \pm 0.32$ \\
\hline & $(0.90-1.06)$ & $(1.00-1.92)$ & $(2.32-2.68)$ & $(2.60-3.50)$ & $(4.00-5.00)$ \\
\hline \multirow[t]{2}{*}{ I } & $0.14 \pm 0.03$ & $0.21 \pm 0.03$ & $0.26 \pm 0.02$ & $0.39 \pm 0.04$ & $0.53 \pm 0.05$ \\
\hline & $(0.10-0.20)$ & $(0.15-0.25)$ & $(0.24-0.32)$ & $(0.35-0.45)$ & $(0.50-0.64)$ \\
\hline \multirow[t]{2}{*}{ II } & $0.17 \pm 0.01$ & $0.42 \pm 0.09$ & $0.62 \pm 0.05$ & $1.07 \pm 0.06$ & $1.69 \pm 0.06$ \\
\hline & $(0.14-0.20)$ & $(0.34-0.67)$ & $(0.52-0.72)$ & $(0.96-1.15)$ & $(1.60-1.80)$ \\
\hline \multirow[t]{2}{*}{ III } & $0.19 \pm 0.01$ & $0.39 \pm 0.03$ & $0.57 \pm 0.04$ & $0.88 \pm 0.04$ & $1.30 \pm 0.06$ \\
\hline & $(0.18-0.22)$ & $(0.35-0.45)$ & $(0.48-0.64)$ & $(0.80-0.95)$ & $(1.20-1.40)$ \\
\hline \multirow[t]{2}{*}{ IV } & $0.44 \pm 0.03$ & $0.63 \pm 0.06$ & $0.85 \pm 0.07$ & $1.12 \pm 0.09$ & $1.46 \pm 0.09$ \\
\hline & $(0.40-0.48)$ & $(0.50-0.74)$ & $(0.72-0.96)$ & $(0.88-1.20)$ & $(1.30-1.60)$ \\
\hline \multirow[t]{2}{*}{ THL } & $0.60 \pm 0.02$ & $1.00 \pm 0.03$ & $1.36 \pm 0.06$ & $2.17 \pm 0.17$ & $3.94 \pm 0.27$ \\
\hline & $(0.56-0.64)$ & $(0.95-1.05)$ & $(1.28-1.48)$ & $(1.93-2.50)$ & $(3.20-4.00)$ \\
\hline \multirow[t]{2}{*}{ THW } & $0.90 \pm 0.04$ & $1.54 \pm 0.40$ & $2.41 \pm 0.28$ & $3.94 \pm 0.23$ & $6.38 \pm 0.29$ \\
\hline & $(0.84-0.98)$ & $(1.00-2.01)$ & $(1.92-3.00)$ & $(3.62-4.43)$ & $(6.00-6.90)$ \\
\hline \multirow[t]{2}{*}{$\mathrm{AL}$} & $0.61 \pm 0.13$ & $1.19 \pm 0.15$ & $1.69 \pm 0.24$ & $2,82 \pm 0.46$ & $3.74 \pm 0.52$ \\
\hline & $(0.40-0.86)$ & $(0.96-1.44)$ & $(1.32-2.04)$ & $(2.19-3.44)$ & $(2.90-4.50)$ \\
\hline \multirow[t]{2}{*}{ AW } & $1.53 \pm 0.08$ & $2.00 \pm 0.15$ & $2.92 \pm 0.30$ & $4.4 \pm 0.46$ & $6.32 \pm 0.48$ \\
\hline & $(1.42-1.66)$ & $(1.67-2.20)$ & $(2.48-3.44)$ & $(3.81-5.04)$ & $(5.20-7.00)$ \\
\hline
\end{tabular}



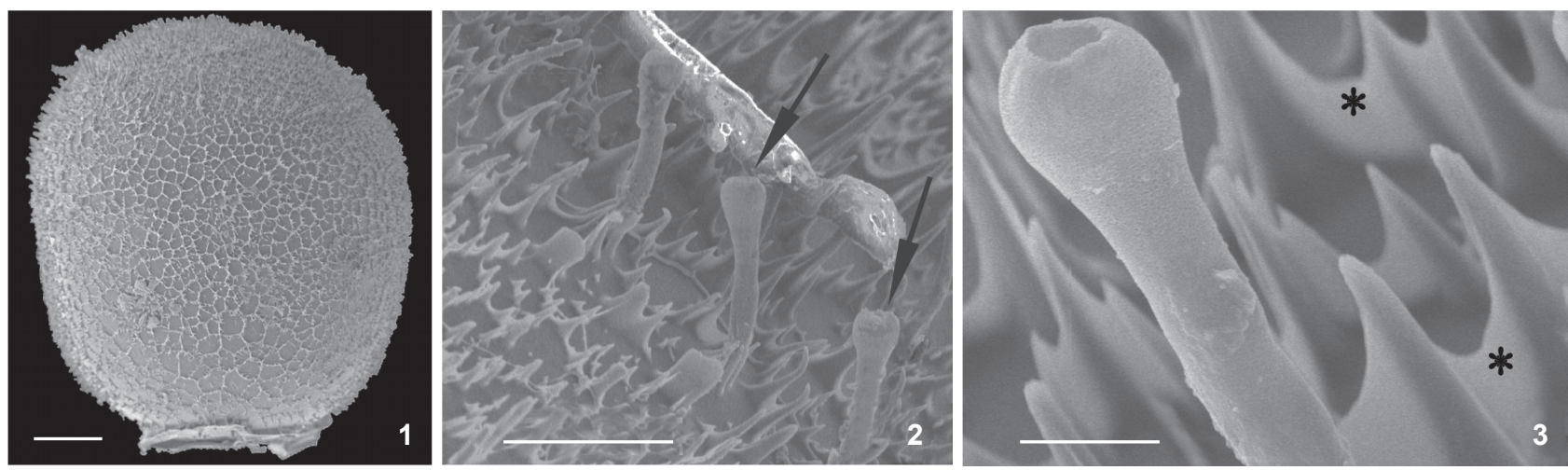

Figures 1-3. Egg of Euschistus (Mitripus) grandis under scanning electron microscopy: (1) lateral view; (2) magnification of anterior pole showing aero-mycropilar processes (arrow); (3) aero-mycropilar process; spines connected by thin sheets (asterisk). Scale bars: $1=200 \mu \mathrm{m}$, $2=50 \mu \mathrm{m}, 3=100 \mu \mathrm{m}$.

First instar (Figs 4, 6 and 12). Body oval, dorsally convex (Fig. 12); light brown just after hatching, changing to red and dark brown after a few minutes. Short setae uniformly distributed over body. Head declivous, subtriangular, dark brown with concolorous punctures. Tylus longer than juga, rounded at apex. Eyes red, ocelli absent. Antennal segments light brown, translucent, intersegmentar areas unpigmented; proportion of antennal segments: $\mathrm{I}=\mathrm{II}=\mathrm{III}<\mathrm{IV}$, segment IV two times longer than each of the previous segments. Rostrum light brown, reaching metacoxae. Thorax brown, punctures concolorous; intersegmentar lines conspicuous; lateral margins smooth, convex, with few setae. Legs light brown, tarsi darker. Sternum reddish. Abdomen red, black punctures denser than on thorax, absent on sternites; intersegmentar lines inconspicuous; four median dorsal plates, brown, subrectangular, the anterior three bearing $1+1$ ostioles. Anterior DAG with slit-like ostiole continued by a short groove; cuticle surrounding ostiole smooth, lacking ornamentation. Lateral plates dark brown. Median and posterior DAGs with ear-shaped ostiole; cuticular process projected toward ostiole (Fig. 6). Groove behind ostiole transposing a granulated area. Ventral median plates brown, conspicuous on segments $\mathrm{V}$ to VIII. Spiracles on segments II to VII; $1+1$ trichobotria on segments III to VI placed mesial to spiracles line (Fig. 4).

Second instar (Figs 5, 7 and 13). Head subquadrangular, less declivous and denser punctured than first instar; dark spots near eyes and on margins of juga; proportion of antennal segments: I < II = III < IV (Fig. 13). Rostrum reaching base of abdomen. Ventral surface of head dark brown. Thorax brown to ivory, denser punctured than first instar; pronotum with $1+1$ dark brown irregular areas. Lateral margins serrate, compressed and slightly deflected, unpunctured. Ventral surface of thorax dark brown. Abdomen dorsally convex, red to ivory with red striation, denser punctured than first instar. Lateral plates lighter than disc, translucent, and outlined in dark brown; lateral margins minutely serrate to smooth. Dorsal median plates punctured. Anterior DAGs bearing wrinkles around ostiole. Median and posterior DAGs with rounded ostiole bearing closing cuticular valve (Fig. 7). Spout peritreme flat and curved anteriorly; posterior peritreme with broader apex than median. Evaporatorium network-shaped surrounding ostiole plus peritrema; alveoli surface with trabeculae; periostiolar groove wrinkled. Ventral surface of abdomen sparsely punctured near lateral margins, unpunctured on disc; $2+2$ trichobotria on segments III to VII (Fig. 5). Other characters as described for preceding instar.

Third instar (Figs 8, 9 and 14). Head ivory with light brown spots; antennal segment III and distal half of IV reddish, remaining areas light grey to white (Fig. 14). Thorax ivory with light brown spots, humeral angles reddish-brown; lateral margins of pronotum deflected. Abdomen red to ivory with red striation, or variegate in green, red, and ivory; lateral plates translucent to greenish, with rare punctures. Median and posterior DAGs with a broader evaporatorium than previous instar (Fig. 8); alveoli covered by trabeculae; periostiolar groove deeper than preceding instar (Fig. 9). Ventral surface of abdomen red with irregular ivory spots. Other characters as described for preceding instars.

Fourth instar (Figs 10 and 15). Head green with brown spots; tylus and juga subequal; antennal segment II lighter (Fig. 15). Thorax greenish; humeral angles with brown spots, margins finely serrate; developing wing pads reaching abdominal segment III. Ventral surface of thorax light brown. Abdomen greenish with small irregular ivory areas; outline of lateral plates interrupted medially. Median and posterior DAGs with broader evaporatorium than previous instar; median peritreme with sharp apex (Fig. 10). Ventral surface of abdomen ivory with reddish spots; spiracles dark brown. Other characters as described for preceding instars.

Fifth instar (Figs 11 and 16). Head with tylus and juga outlined in black; lateral margins of juga deflected; proportion of antennal segments: I < II > III = IV (Fig. 11). Rostrum green at base. Thorax dark brown on humeral angles and apex of wing pads; humeral angles truncate, prominent; wing pads reaching abdominal segment IV. Ventral disc of thorax greenish, includ- 


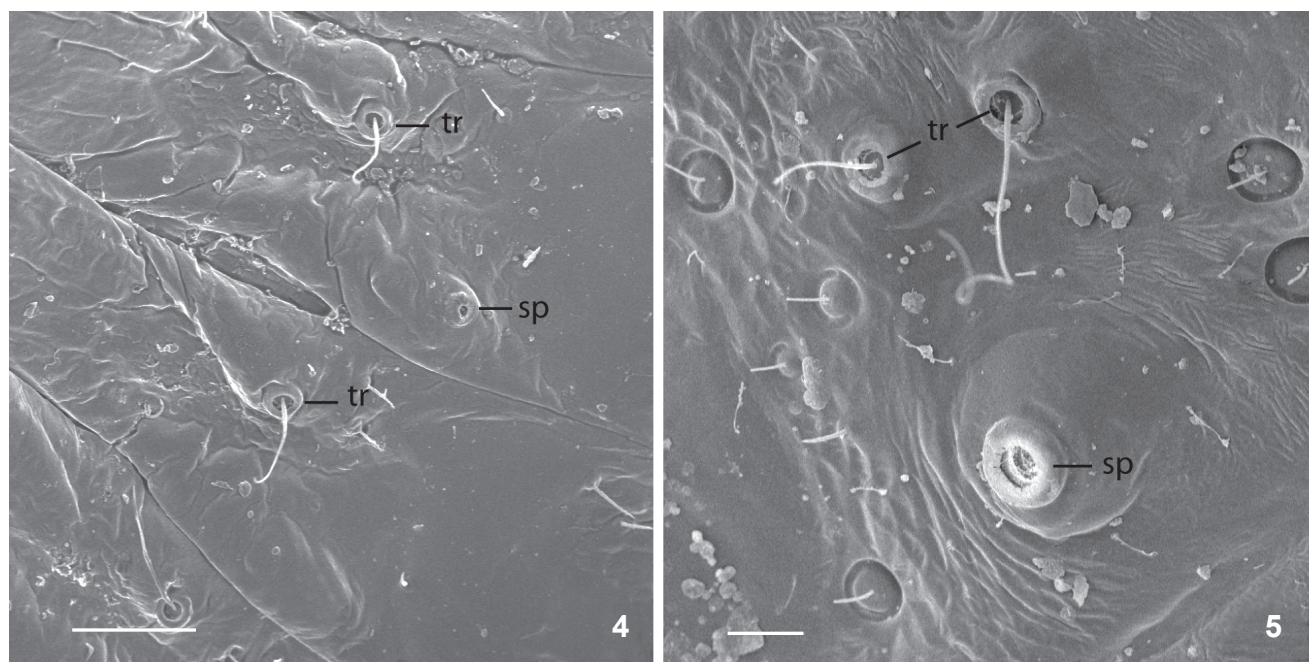

Figures 4-5. Lateral margin of abdominal segments of Euschistus (Mitripus) grandis under scanning electron microscopy: (4) first instar, segments IV-V; (5) second instar, segment V. (sp) spiracle, (tr) trichobothrium. Scale bars: $4=50 \mu \mathrm{m}, 5=20 \mu \mathrm{m}$.
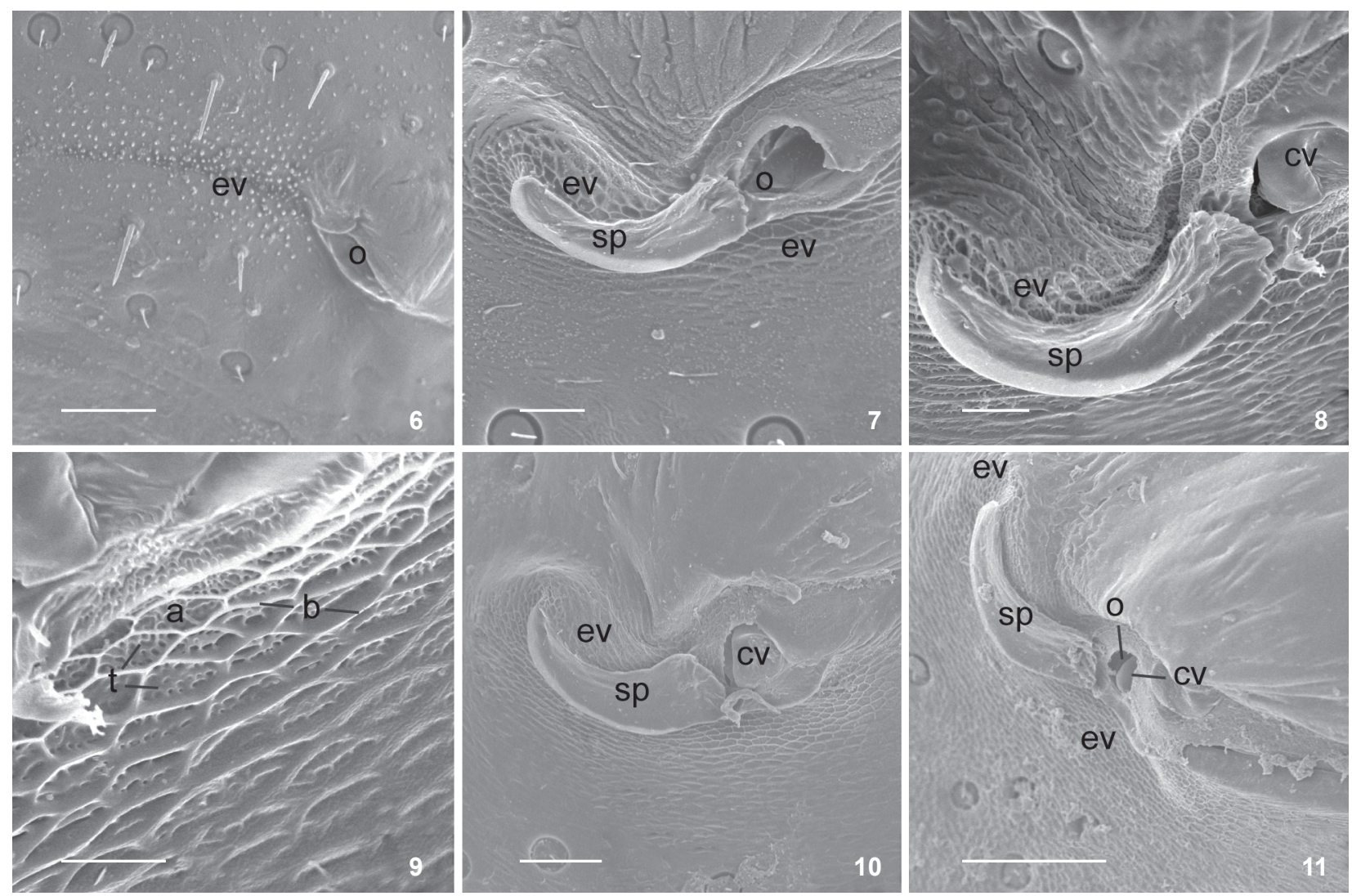

Figures 6-11. External cuticular structures of median dorsal abdominal gland of nymphs of Euschistus (Mitripus) grandis under scanning electron microscopy: (6) first instar; (7) second instar; (8) third instar; (9) magnification of evaporatorium, third instar; (10) fourth instar; (11) fifth instar. (a) Alveole, (b) bridges, (cv) cuticular valve, (ev) evaporatorium, (o) ostiole, (sp) spout peritreme, (t) trabeculae. Scale bars: $6,10=50 \mu \mathrm{m}, 7-8=20 \mu \mathrm{m}, 9=10 \mu \mathrm{m}, 11=100 \mu \mathrm{m}$. 


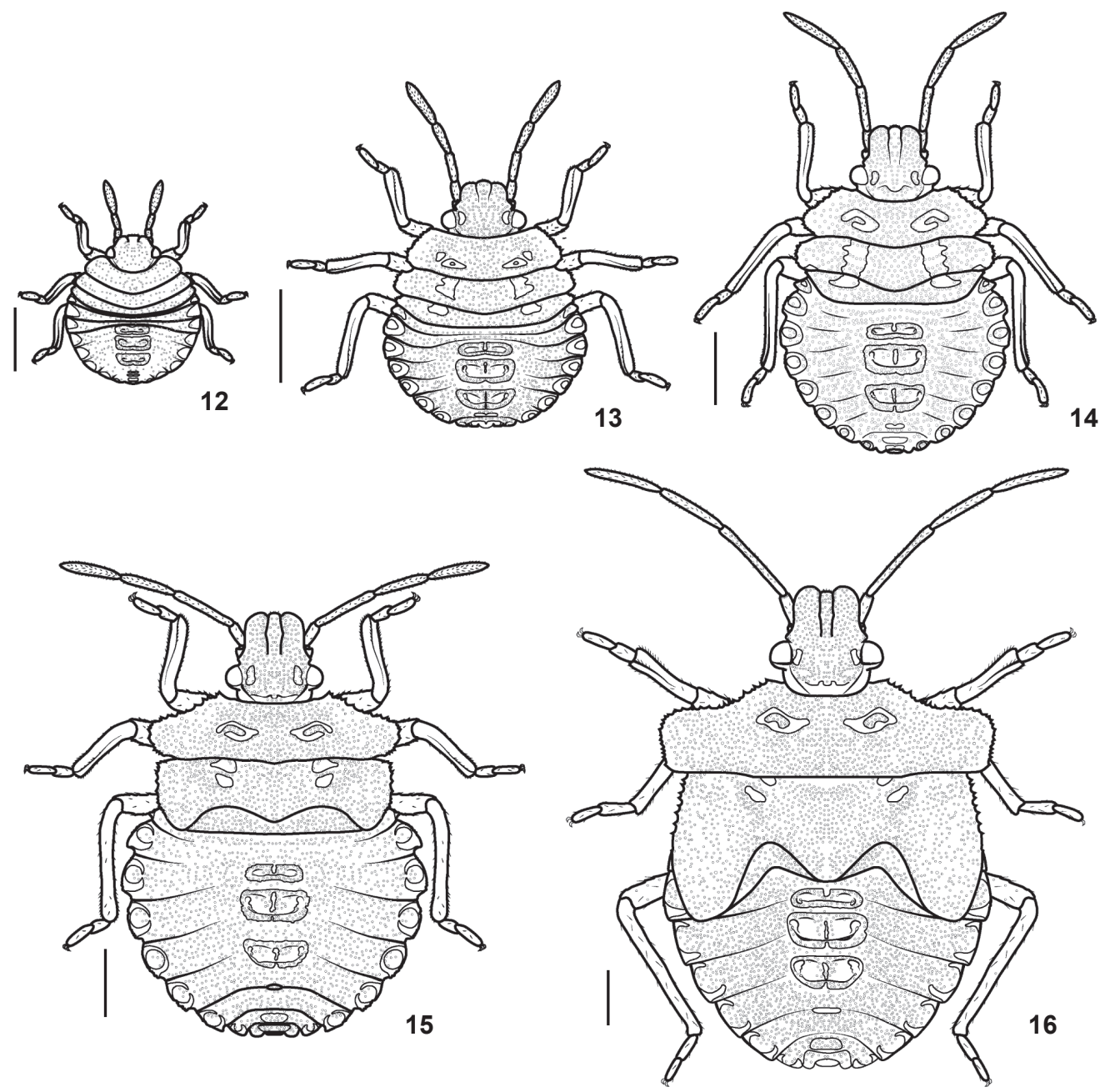

Figures 12-16. Euschistus (Mitripus) grandis nymphs, first to fifth instar, respectively, dorsal view. Scale bars $=1 \mathrm{~mm}$.

ing coxae. Abdomen with green median plates; evaporatorium broader than preceding instar (Fig. 16). Intersegmentar lines conspicuous. Lateral margins of segments II and III minutely serrate. Ventral surface of abdomen variegate in green, red and ivory. Other characters as described for preceding instars.

\section{DISCUSSION}

Since most immatures described belong to species of agricultural interest and these are not necessarily closely related species, the information about immature morphology is scattered in the family, making it difficult to recognize patterns within subgroups of Pentatomidae. However, considering that Euschistus and Carpocorini are the best studied groups, some relevant comparisons can be made here. The eggs of Euschistus fit the external morphology commonly found in Carpocorini (Matesco et al. 2009), namely translucent eggs with spinose chorion. Besides these characteristics, the eggs of $E$. (M.) grandis resemble those of other species of Euschistus by the barrel shape and convex operculum (Brailovsky et al. 1992, Martins \& Campos 2006, Matesco et al. 2009, CANDAN et al. 2005). Similar chorion sculpture as found in E. (M.) grandis, with irregular polygons formed by thin sheets connecting spines, was reported for all species of Euschistus already studied under SEM (MATESCO et al. 2009, Candan et al. 2005, Bundy \& McPherson 2000). Two species, Euschistus (E.) ictericus (Linnaeus, 1763) and E. (E.) sulcacitus Rolston, 1971, had their chorion described under light microscopy, the first as reticulate with spines (McPherson \& PASKEwITZ 1984 ) and the second as bearing "many setae" (BRAILOvsKy et al. 1992). Further comparisons are not possible because the two species were not studied under SEM.

Few species of Pentatomidae had diagnostic characters described to enable their identification prior to the adult stage (e.g., Gilio-Dias et al. 2013). Nymphs of E. (M.) grandis can be 
distinguished from other species of Euschistus by the color pattern and morphological features. From $1^{\text {st }}$ to $3^{\text {rd }}$ instar most nymphs of Euschistus are morphologically similar (MARTINS \& Campos 2006, McPherson \& Paskewitz 1984, Grazia et al. 1980, BrallovsKy et al. 1992, PARISH 1934), but only E. (M.) hansi presents a color pattern as seen in E. (M.) grandis, although nymphs of the former are about $1 / 3$ smaller than the latter and thus easily distinguishable. In $4^{\text {th }}$ and $5^{\text {th }}$ instars predominantly greenish nymphs as in $E$. (M.) grandis were described for $E$. (E.) variolarius (Palisot, 1817). The latter can be distinguished from the former by the presence of black and red spots (PARISH 1934). The most striking morphological characteristic of $4^{\text {th }}$ and $5^{\text {th }}$ instar nymphs of $E$. (M.) grandis is the broad, deflected projection of humeral angles, the latter feature also present in E. (E.) sulcacitus and $E$. (E.) bifibulus (Palisot de Beauvois, 1805) (Brallovsky et al. 1992).

During nymphal ontogenesis the anterior DAG pair changes only by the increment of wrinkles around the ostioles, whereas the median and posterior DAGs are progressively more complex and with a wider evaporatorium. The external ontogeny of DAGs is considered to include only the expansion of the evaporatorium (VILÍMOVÁ \& KuTALOVÁ 2012), although our results indicate that the occurrence of fine structural modification should be better investigated. We suggest the description of DAGs under SEM should become a standard practice in future morphological studies of nymphs. Such practice will provide a better understanding of the comparative morphology of the DAGs across different taxonomic levels. We also indicate as character sources for phylogenetic studies the chorion sculpture, the structure of AMP, and the cuticular structure of DAGs, all under SEM.

\section{LITERATURE CITED}

Bianchi, F.M.; V.C. Matesco; L.A. Campos \& J. Grazia. 2011. External morphology of the egg and the first and fifth instars of Cyrtocoris egeris Packauskas \& Schaefer (Hemiptera: Heteroptera: Pentatomidae: Cyrtocorinae). Zootaxa 2991: 29-34.

Brallovsky, H.; L. Cervantes \& L. Mayorga. 1992. Hemiptera: Heteroptera de México XLIV. Biología, estadios ninfales y fenología de la tribu Pentatomini (Pentatomidae) en la Estación de Biología Tropical "Los Tuxtlas". Ciudad de México, Universidad Nacional Autonoma, Instituto de Biología (Publicaciones Especiales 8), 204p.

Bundy, C.S. \& R.M. MCPHERson. 2000. Morphological examination of stink bugs (Heteroptera: Pentatomidae) eggs on cotton and soybeans, with a key to genera. Annals of the Entomological Society of America 93 (3): 616-624.

Campos, L.A.; J. Grazia; T.A Garbelotto; F.M. Bianchi \& N.C. LanzarinI. 2010. A new South American species of Banasa Stål (Hemiptera: Heteroptera: Pentatomidae: Pentatominae): from egg to adult. Zootaxa 2559: 47-57.

Candan, S.; Z. Suludere \& F. Açırgöz. 2005. Chorion morphology of eggs of the North American stink bug Euschistus variolarius (Palisot de Beauvois, 1817) (Hemiptera: Pentatomidae): a scanning electron microscopy study. Entomological News 116 (3): 177-182.

Gilio-Dias, S.M.; L.A. Campos \& F.M. Bianchi. 2013. Morphology of immatures of Caonabo pseudoscylax (Bergroth) (Hemiptera: Pentatomidae). Neotropical Entomology 42 (2): 178-184.

Grazia, J.; M.C. del Vecchio; F.M.P. Balestieri \& Z.A. Ramiro. 1980. Estudo das ninfas de pentatomídeos (Heteroptera) que vivem sobre soja (Glycine max (L.) Merril): I - Euschistus heros (Fabricius, 1798) e Piezodorus guildinii (Westwood, 1837). Anais da Sociedade Entomológica do Brasil 9 (1): 39-51.

Grazia, J.; N.D.F. Fortes \& L.A. Campos. 1999. Pentatomoidea, p. 101-112. In: C.A. Joly \& C.E.M. BICUdo (Eds). Biodiversidade do Estado de São Paulo, Brasil: síntese do conhecimento ao final do século XX. São Paulo, FAPESP, vol. 5, XIII+279p.

Grazia, J.; R.T. Schuh \& W.C. Wheeler. 2008. Phylogenetic relationships of family groups in Pentatomoidea based on morphology and DNA sequences (Insecta: Heteroptera). Cladistics 24 (6): 932-976.

HASAN, S.A. \& I.J. Kitching. 1993. A cladistic analysis of the tribes of Pentatomidae (Heteroptera). Japanese Journal of Entomology 61 (4): 661-669.

HenRY, T.J. 1997. Phylogenetic analysis of family groups within the Infraorder Pentatomomorpha (Hemiptera: Heteroptera) with emphasis on the Lygaeoidea. Annals of the Entomological Society of America 90 (3): 275-301.

KMent, P. \& J. ViLímovÁ. 2010. Thoracic scent efferent system of Pentatomoidea (Hemiptera: Heteroptera): a review of terminology. Zootaxa 2706: 1-77.

Martins, F.S. \& L.A. CAmpos. 2006. Morfologia e biologia dos imaturos de Euschistus hansi (Hemiptera, Heteroptera, Pentatomidae). Iheringia, Série Zoologia 96 (2): 213-218.

Matesco, V.C.; C.F. Schwertner \& J. Grazia. 2006. Descrição dos estágios imaturos de Chinavia erythrocnemis (Berg) (Hemiptera, Pentatomidae). Neotropical Entomology 35 (4): 483-488.

Matesco, V.C.; C.F. Schwertner \& J. Grazia. 2007. Descrição dos estágios imaturos e biologia de Chinavia pengue (Hemiptera, Pentatomidae). Revista Brasileira de Entomologia 51 (1): 93-100.

Matesco, V.C.; B.B.R.T. FÜrSTenaU; J.L.C. Bernardes; C.F. SCHWERTNer $\&$ J. Grazia. 2009. Morphological features of the eggs of Pentatomidae (Hemiptera: Heteroptera). Zootaxa 1984: 1-30.

McPherson, J.E. \& S.M. PASKewitz. 1984. Life history and laboratory rearing of Euschistus ictericus (Hemiptera: Pentatomidae), with descriptions of immature stages. Journal of the New York Entomological Society 92 (1): 53-60.

Mendonça Jr, M.S.; C.F. Schwertner \& J. Grazia. 2009. Diversity of Pentatomoidea (Hemiptera) in riparian forests of southern Brazil: taller forests, more bugs. Revista Brasileira de Entomologia 53 (1): 121-127.

PARISH, H.E. 1934. Biology of Euschistus variolarius P. de B. (Family Pentatomidae; Order Hemiptera). Annals of the Entomological Society of America 27 (1): 50-54. 
Pollo, P.; C. Greve; V.C. Matesco \& J. Grazia. 2012. Description of the immature stages of Glyphepomis spinosa Campos \& Grazia (Hemiptera: Pentatomidae: Pentatominae: Carpocorini). Zootaxa 3566: 61-68.

Rolston, L.H. 1978. A new subgenus of Euschistus (Hemiptera: Pentatomidae). Journal of the New York Entomological Society 86: 102-120.

Schwertner, C.F.; G.S. Albuquerque \& J. Grazia. 2002. Descrição dos estágios imaturos de Acrosternum (Chinavia) ubicum Rolston (Heteroptera: Pentatomidae) e efeito do alimento no tamanho e coloração das ninfas. Neotropical Entomology 31 (4): 571-579.
VilímovÁ, J. \& K. KuTALOVÁ. 2012. Occurrence of certain cuticular structures confirms functionality of dorsal abdominal scent glands in Acanthosomatidae (Heteroptera: Pentatomoidea). Bulletin of Entomological Research 102 (1): 29-42.

WHEELER, W.C.; R.T. SCHUH \& R. BANG. 1993. Cladistic relationships among higher groups of Heteroptera: congruence between morphological and molecular data sets. Entomologica Scandinavica 24 (2): 121-137.

Yonke, T.R. 1991. Order Hemiptera, p. 22-65. In: F.W. STEHR (Ed.). Immature insects. Dubuque, Kendall, Hunt Publishing Company, vol. 2, 975p.

Submitted: 18.I.2013; Accepted: 20.V.2013.

Editorial responsibility: Gabriel L.F. Mejdalani 